\title{
Development of Manufacturing System in the Industrial Revolution 4.0 from Concept to Industrial World
}

\author{
Iwan Harianton ${ }^{1}$, Heri Setiawan ${ }^{2}$, Agus Surjana Saefuddin ${ }^{3}$ \\ 1,2,3 Manufacturing Technology and System, Politeknik Manufaktur Bandung
}

Email: ihar@polman-bandung.ac.id

Informasi Artikel: ABSTRAK

Received:

25 Februari 2020

Accepted:

04 April 2020

\section{Available:}

08 Mei 2020

\section{Kata Kunci:}

Sistem manufaktur Revolusi Industri 4.0 Teknologi digital Indikator kinerja utama

OEM
Pengembangan industri di negara-negara mulai maju menjadi sangat menarik bagi pemanufaktur peralatan orisinil sejak sepuluh tahun terakhir dengan bukti makin kuatnya kehandalan sistem industrial yang dikembangkan oleh negara-negara tersebut secara terpisah. Khususnya, setelah publikasi pemerintah Jerman dengan tajuk Revolusi Industri 4.0 ditandai oleh pabrik pintar, dimana lebih banyak teknologi digital dikreasikan dan diterapkan di pasar. Periode unik ini dikenal sebagai inovasi disruptif dimana generasi sebelum milenial masih pada posisi produktif sementara teknologi digital menggantikan hampir semua alat dari profesional tersebut dengan mengabaikan peralatan praktis yang digunakan selama ini. Oleh karena itu, sementara perubahan sangat cepat berjalan terus menerus, sebagian besar aspek produktif dari komunitas menyambut positif kepada generasi mudanya dengan memberikan arena produktifnya melalui pergantian kepemimpinan unggulnya secara damai. Dunia manufaktur sebagai salah satu arena yang sangat jelas terlihat merespon inovasi disrupsi dengan memetakan persyaratan sistem dengan mentransformasikan perusahaan tradisional menjadi perusahaan manufaktur kelas dunia. Proses transformasi cepat di dunia manufaktur dilakukan pada pemasok dari hampir semua pemanufaktur peralatan orisinil dengan menstrukturkan level pembangunan sistem manufakturnya dan meningkatkan peralatan produksi dengan teknologi digital dan juga mempertahankan indikator kinerja utamanya sebagai pemasok handal. Rekaman perjalanan perbaikan tersebut diteliti dan dibuat tersedia ke publik melalui agen pemerintah lokal sehingga perusahaan menengah dapat memenuhi permintaan persyaratan pemasufaktur peralatan orisinil. Metodologi pengembangan sistem manufaktur di uraikan dalam tulisan ini termasuk benefit bagi kebanyakan perusahaan yang sedang mengejar posisi pesaing kelas dunia.

\section{ABSTRACT}

Industrial development in the new emerging countries were becoming attractive to OEM manufacturers since a decade ago by proofing stronger reliability of the industrial system enhanced by most countries separately. Especially, after the publicity of the German Government's campaign on its Industrial Revolution 4.0 by smart factory, where more and more digital technology being created and launched to the market. This unique period is called the disruptive innovation where previous generation before millennials are still in the productive ages while all the digital techies invades almost all professional tools regarding of the common practices used by them. However, while such rapid changes are continuously occurring, most productive aspects of communities' response positively to their youngsters by letting them lead most of the productive arenas with their excellent seamless leadership handover. The manufacturing world is among the leading sectors to response to the disruptive innovation by 
mapping all the system's requirement to be implemented by millennial for responding the global world by structuring the concept of communitybased companies into world class manufacturers. The process of rapid transformation in the manufacturing world was done in the suppliers of most OEM companies by structuring levels of their manufacturing system and enhancing facilities by equipping digital technology in their production machineries and also satisfying the key performance indicators of being reliable vendors. The enhancement track records were researched and made available to public by the local government agents so that more medium scale companies could cope with their projects of supplying goods to meet OEM companies' requirement. The methodology of manufacturing system development is discussed in this paper including the benefits for some industries leading to catch up with their own development programs leading to global competitive players. 
Development of Manufacturing System in the Industrial Revolution 4.0 From Concept to Industrial World

\section{INTRODUCTION}

Industrial revolution 4.0 has been materialized by numerous facilities available for human easiness including smart phone, smart home, smart cars, smart city and even already declared smart nations [1]. The main talk was concerning the digital transformations across all the shareholder partnerships so that all human amenities featured by low consumption of energy, eco-friendly, disposable materials, harmless to the living being, and prolonged natural resources for generations to come. It talked about opportunities and threats along with the technology that cannot be imagine 50 year back, the world now entering the era of Industrial Revolution 4.0, where digital economy, artificial intelligence, big data, robotic, and wave technology being used to help human activities with bunches of easiness but it acutely carrying high risk on advanced technology. Now the hidden consequence of the technology has been opened up one by one, which we all may not be aware of. The key issue is what will be the features of manufacturing business in the years to come?

There will be three key words that will be discussed in this paper namely manufacturing, system and development stages. Manufacturing comes from Latin words, manu and factus. Manu stands for made, while faktus stands for hands, so manufacturing stands for something that is made by hands or adding value to the original material into something that is valuable for human productive activities. In the international consensus, manufacturing covers engineering, design, production, and installation, which are managed under ISO9001:2015 quality management system standard. System in this document is defined as the activities starting from input, process, and output which are requires resources to materialized input and often equipped by feedback to make productivity level of the operation improved in time. The last word is development stages, which stands for the methodology to reach an ideal value of the manufacturing system. Later the development stages will be measured under a set of key performance indicators which will be recorded once a while in the process to lead into the state of the world class manufacturing player.

Furthermore, the key performance indicators could represent the actual manufacturing system that undergone process of the series development.

\section{INDUSTRIAL REVOLUTION 4.0}

In the footprint of industrial revolutions, there had been occurred and agreed by many scholars existed in four stages. Each revolution had been simplified by international consensus to be figured in figure 1 , which stamp different milestone affected to human life activities and economic development worldwide [2].

Industrial Revolution $\mathbf{1 . 0}$ marked by human effort on mechanical tools on production after the invention of steam energy by James Watt and soon becoming obsolete in the world war I where mass production and mass assembly were invented after the Electricity Energy was introduced, then Industrial Revolution $\mathbf{2 . 0}$ occurred followed by automotive mass production invented by Henry Ford, which convey very famous sarcastic terms declared as "You can buy any color of automobiles, as long as it is black". Such term then became last after less than 50 years where computer technology and flexible automation really exist in the production line imitated through the supermarket system that balanced demand by continuous supply under zero waste philosophy on flexible production, which later known as the Industrial Revolution 3.0. 
Further development has been speeding up through the development of computer technology and modern digital concept to improve the quality of product using CAD/CAM/CAE technology and styling that followed by operation of shop floor based on Lean operation to reach zero waste. No more than 30 years, now Industrial Revolution 4.0 was introduced in early millennial age that affect our life today and in the future. Such phenomenon has been titled "disruptive innovation" because in the middle of happy and stable professional practices, young generation had successfully codified US-Army unseen technology becoming commercial and even offers huge opportunity of human life activities. The momentum was made available based on digital technology on the computer-based machines and wide-network that promote intelligent products to assist human transaction using cloud computation that able to handle big data through Internet of the Things (IoT).

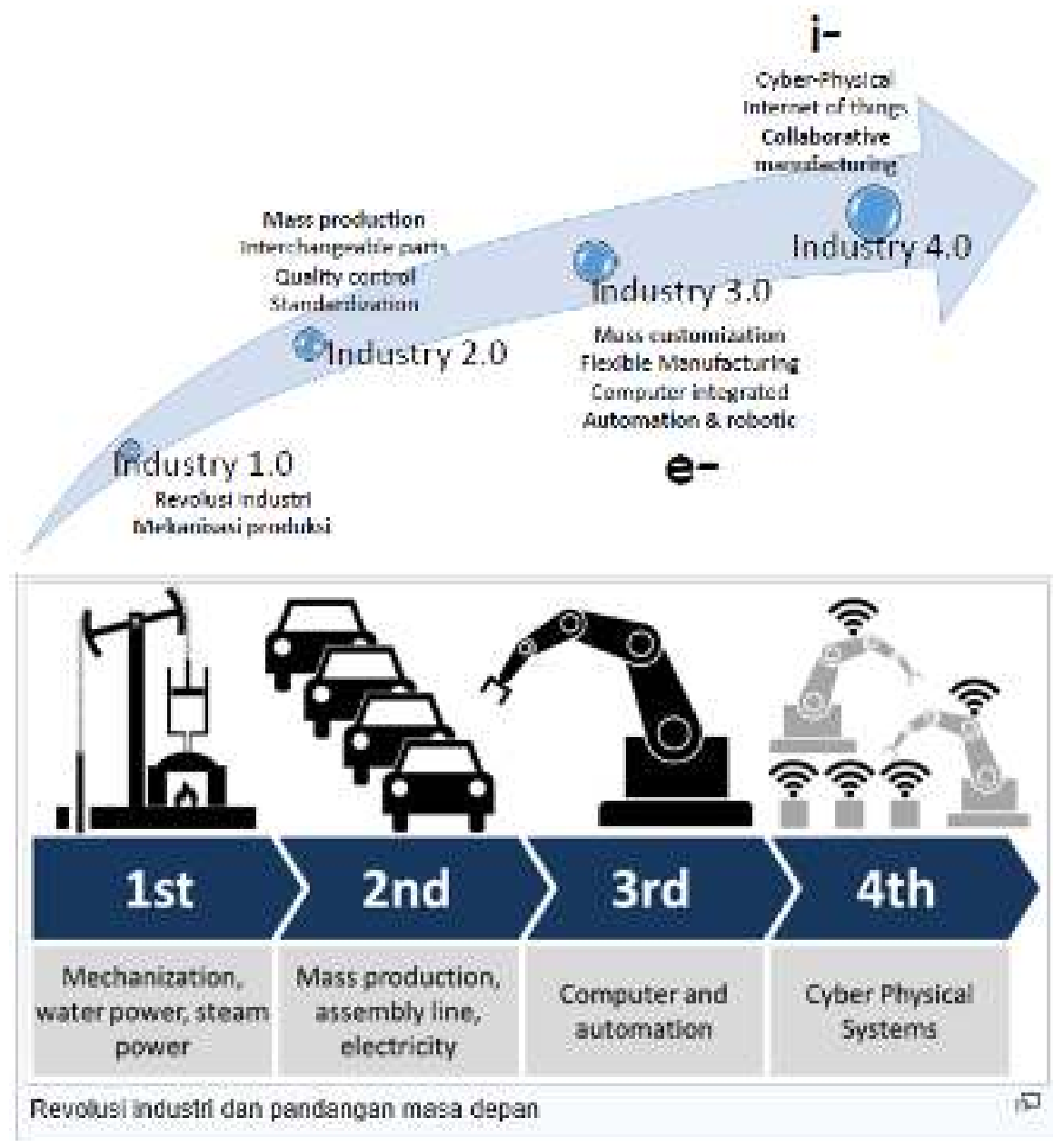

Figure 1. Industrial Revolution 1 to 4

Kohler and Weiz [2] defines the Industrial Revolution 4.0 as the tools to handle production proses on-line by providing synchronization of production line for special products or standard. Trappey et.al., [3] describes the Industrial Revolution 4.0 as the general concept that allows the manufacturing proses run under the tactical and intelligent resources using IoT technology, cloud computing, and smart products based on computing big data. So that we can understand that Industrial Revolution 4.0 development has been pushed by the existence of digital technology working on the cloud computer technology that can handle 
big data on the wide network of global internet system, which eventually affect every aspects of human activities through smart products. Artificial Intelligence come in contact to add value to the millennial products variety.

\section{PROBLEMS STATEMENT OF IOT TECHNOLOGY AND ITS CHARACTERISTIC}

Assemble the IoT technology with the development of manufacturing system on the already IoT based technology should be first identified by all major executors of reformation. Industries that are currently affected by IoT technology had been published by Nate William [4], which displayed in figure 2 with three smart layers including:

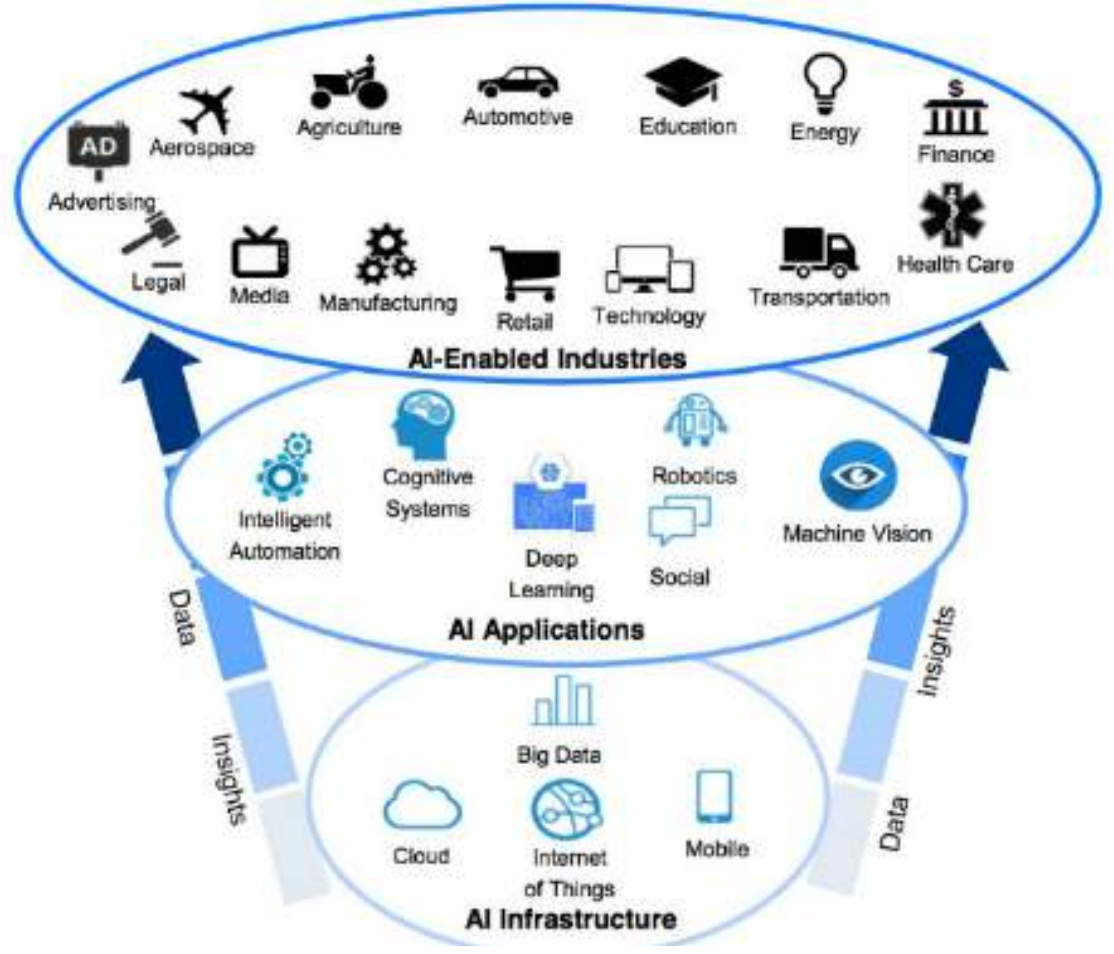

Figure 2. Three layers of smart technology

1. Smart Layer called infrastructure including IoT, Mobile device, Cloud computing, and Big data.

2. Smart Layer applications including intelligent automation, cognitive system, deep learning, robotic, social, dan machine vision.

3. Smart Layer Industrial level including Education, Energy, Finance, Health Care, Transportation, Home Technology, retailer, Manufacturing, Media, Law \& Regulation, Advertising, Aerospace, Agriculture, and Automotive.

The three layers of IoT technology contains 7-characters interconnected that can change data to information that valuable for human life; furthermore, Nate Williams defines those as follows:

Connectivity: Tools and machines, sensor should be connected to internet network, Things: production machines or proses that equipped with sensors that are links to others, Data: are introduced to internet as the basis for intelligent analysis, Communication: link of process parameters with data that can be analyzed, Intelligence: level of intelligence to 
analyze data available in the network through application of artificial intelligence, Action: will be the follow up to process after decision made manually or automatically as the very important character, Ecosystem: will be the perspective of IoT apart from the other technology, community, achievement and figures where IoT can provide value for human life.

Then, the development manufacturing system entering the Industrial Revolution 4.0 consists not only the system development but also the technology readiness to fufill the demand of the wide customer demands that are most probably driven by group of millennials that are already well exposed by the IoT technology [5].

\section{METHODOLOGY}

Development of manufacturing system will be driven by already establish references from east and west worlds that influence strongly on the process of advancing the manufacturing system development today. Therefore, the methodology is selected based on the key performance indicators of the system and the tools that should present to facilitate youngsters in performing the development process.

The development process will target certain level of its performance indicators which are prioritized based on the analysis of the urgency and important criteria that lead to a certain improvement activities using appropriate tools, then the methodology is verified based on a set of generic rubrics that describe the position of the development stages accomplished.

The key performance indicators of the manufacturing system development consists of five stages: first stage is regarding the capacity to deliver correct product quality, second stage is regarding the safety, third stage is regarding the facility breakdown, fourth stage is about ecosystem, and the fifth stage is about social responsibility. In the eastern world, they are represented by zero qualities such as zero defect or zero waste, while the western world they are represented by six-sigma values.

\section{DEVELOPMENT PROCESS}

\subsection{First Stage}

Manufacturing system development starts from its reforming capacity to deliver correct quality products for their customers. The entry competitive class level is to confirm with the ISO 9001:2018 quality management system. The manufacturing system will be secured to deliver output consistently overtime. The main development is to lead into lean manufacturing system, which deliver no waste in the production process. Practitioners manage 7-waste plus one to be prominent world class competitors and awarded "/ean manufacturing system" operation. The waste include overproduction, inventory, motion, process, transportation, waiting time, and reject/rework, plus underutilized human talent. The award can be reached using tools such as Kaizen cycle, or Six-sigma methodology. Both tools are widely used by OEM companies worldwide.

Besides, lean production process operation the manufacturing system development also concerns with the product engineering, and production engineering. Product engineering concerns about delivering product concept to detail product specification. Meanwhile, production engineering concerns with the handling of raw material, inventory, plant layout and finished product delivery and installation to the users. IoT technology is even obvious even in the early stage especially in the raw material supply and customer demands. The 
additive manufacturing was very critical to the product engineering especially when the solid model can be fed into the additive manufacturing machines within hours the product features can be shown to the customers.

\subsection{Second Stage}

When the capacity to deliver high quality products are in the positive track, then the second key performance indicators comes up concerning the safety of the operation. People commonly says that "safety first", yes, it is quite correct, but the mean come after people works to deliver products in a consistent interval.

The safety operation has been standardized under ISO 45001:2018, which was formerly regulated under ISO18001. The accident happens when the three conditions occurs at once, that are lack of human focus, unsafe machine condition and unhealthy environment. When human focus is prima, the person can identify unsafe machine condition as well as to avoid influence of the unhealthy environment, then accident fail to occur. The key factor of avoiding accident is to manage safe working environment equipped by several safety tools including emergency response or safety evacuation, work site analysis, equipment safety, hazard prevention and control, occupational safety standard, and health promotion. There should be a few professionals who are trained to be the safety officers spread across manufacturing operation as the basis of first emergency aid.

\subsection{Third Stage}

The third key performance indicator of developing manufacturing system is to make sure that the facility will serve with zero breakdown. The maintenance concept is gradually changed from design for maintenance to maintenance free products or machineries. It is a practitioner's consensus that maintenance will be wiped out in the future, due to non-added value cost that should be paid by customers. However, some component especially those are subject to maintenance operation are difficult to redesign for free maintenance, then modular based maintenance came in contact to the practitioner's operation, so that the components can be replaced at very little time.

The maintenance management transforms from preventive maintenance to reliability maintenance, where total productive maintenance (TPM) is operated under IoT facilities and censors. Maintenance operation in old days called ISMO or Inspection, Small Repair, Medium Repair and Overhaul were crushed under TPM concept by involving operators to inspect and to make small maintenance based on an Autonomous maintenance operation done by machine operators. Beyond that include medium and overhaul is automated under actual condition monitoring and censors and electronic monitoring system by means of measuring lifetime span that the components can withstand. The TPM utilized the preventive maintenance schedule to inspect main components that reached their lifetime.

\subsection{Fourth Stage}

The next key performance indicator of developing manufacturing system is leading to zero environmental pollution. The operation has been standardized under ISO 14001:2015 concerning the management of environmentally friendly. Such standard covers protection of the environment, open new marketplaces which concerns environment protection, and obeying local government regulation. 
The new emerging countries also now becoming very concern with the environmental protection as it is required by most advanced markets places worldwide. The band could be applied to certain products that are manufactured under unsafe to environmental requirement. The technology to facilitate such regulation is becoming very sophisticated as nano-technology come across with the supply of nano size membrane that can screen most of heavy metal substances come out from the manufacturing operation.

\subsection{Fifth Stage}

Concluding all activities across all key performance indicators of developing manufacturing system is concerning with the social complaint. The operation had been standardized under ISO 26000 after the Social Responsibility Guideline. The standard describes four social focus including ethical focus, stakeholder focus, content focus, and process focus.

Ethical focus is the reasons why every manufacturing system development be aware of Social Responsibility, it concerns with 7-principles including accountability, transparency, ethical behavior, respect to stakeholder interests, respect for rule of law, respect for international norms of behavior, and respect for human rights. Stakeholder focus is the fundamental of social responsibility it includes recognizing social responsibility value chain and sphere of influence, and stakeholder identification and engagement. Content focus is recognized as core value of social responsibility, it covers organizational governance on human rights, labor practices, the environment, fair operating practices, consumer issues, community involvement and development. Finally, the Process focus is to integrate social responsibility throughout the organizational operation, it will cover awareness, competency, setting direction, and integrating into systems.

The above five key performance indicators in developing manufacturing system could be operated in serial or parallel modes depending on the opportunities and threat, that are experiencing by companies developing manufacturing system. Environmental analysis usually come first as the license of operation requires such report. Later, prudence customers ask for such requirement.

Above all, manufacturing system could not be developed overnight, it requires series of effort that most companies grow from scratch may not be aware of. Therefore, a rubrical stages has been prepared to be discussed in the result and discussion section in the form of rubrical explanatory. Figure 3 shows the development stages from level 1 to level 4 that can simplify development stages over period of time.

Level 4: level $3+$ product innovation, social responsibility \& environmentally friendly.

Level 3: level $2+$ every 0 ne involves

in continuous improvenent program

Level 2: level $1+$ excellence value of one or more qualities of QCDSM

Level 1: capability to deliver

standard product/correctly in time

Figure 3. Development stages promoted 


\section{RESULT AND DISCUSSION}

Developing manufacturing system is an effort uniquely done to provide guidelines for the new emerging industrial countries, which are possibly nations across the equators that are not experiencing hardships from the nature.

The nature in those countries are very friendly or very reach so that people are not keen enough to manage their time properly. Therefore, their economic development is somewhat behind. The exception of the leading countries such as Singapore, because it is very small, and lucky enough to earn very strong leadership skill among themselves. So that even though it is in the equator, but their achievement is very substantial.

Others such as Indonesia, Thailand, Vietnam as well as Malaysia are among the emerging industrial countries that very need of this thought. Then, to make such written document complete, the result and discussion will be used to provide evaluation guidelines as the development process occurring.

Level 1 is the entry level of the manufacturing set up, which is marked by its capacity to deliver high quality standard products but the system still delivering wastes. Therefore, the system will be difficult to compete and can only fulfill emergency requirement.

Level 2 is the development of manufacturing system where quality agenda start to be established. The achievement besides capacity to deliver high quality standard products, it presents with advantages over one or more qualities of QCDSM over its competitors. The products of these companies may present in the marketplaces and fit to certain segment of customers. Chinese companies enter global market with this level.

Level 3 is the entry level of global competitors, where the system delivers high quality products, having advantageous on more qualities aspect of the QCDSM, and everyone has continuous improvement agenda to suit with the company's focus. Most Japanese manufacturing set up operate in this level especially using Kaizen cycles to lead the system into zero waste manufacturing operation.

Level 4 is main global players identify by its original equipment manufacturing (OEM) that usually well known by global customers. Several patents registered under such companies and the research and development continuously deliver more sophisticated products for its future markets. The manufacturing set up may only be the assembly set up and its main components, while production of other components could be shared by its reliable suppliers.

\section{FINAL THOUGHT}

The development of manufacturing system is very delicate tasks for most emerging industrial nations. Not only lack of technology but also requires culture shift from waiting behavior to become a deterministic behavior.

The stage of manufacturing system development may not be critical to already advanced industrial countries, but for the new emerging countries such development is very important and painful. More importantly, all major manufacturing installation done by advanced industrial countries gain positive output while local employees done the detail works, which means that not the people to blame, the system that make local people change to be a deterministic employee which make it succeeds. 


\section{REFERENCES}

[1]. Smart Nation Summit (2019), June 26, Marina Bay Sands Convention Center, Singapore.

[2]. Kohler and Weiz, (2016) "An approach to control production process by providing real time synchronization of flows and enabling unitary \& customize production".

[3]. Tappey, et.al., (2016) "A general concept enabling manufacturing with clements of tactical intelligence using advanced IoT, cloud \& big data technology".

[4]. Nate Williams (2017), keep calm and automate to unlock the opportunity in the vertical Internet of Things, Allianz Global, September.

[5]. Gunilla Sivard, Magnus Lundgren KTH, (2018), "A methodology for manufacturing system development, pp31-35, Royal Institute of Technology, Department of Production Engineering, Stockholm, Sweden. 